\title{
A general and facile one-pot process of isothiocyanates from amines under aqueous conditions
}

\author{
Nan Sun ${ }^{1}$, Bin $\mathrm{Li}^{1}$, Jianping Shao ${ }^{1}$, Weimin $\mathrm{Mo}^{* 1}$, Baoxiang $\mathrm{Hu}^{1}$, \\ Zhenlu Shen ${ }^{1}$ and Xinquan $\mathrm{Hu}^{* 1,2}$
}

\section{Full Research Paper}

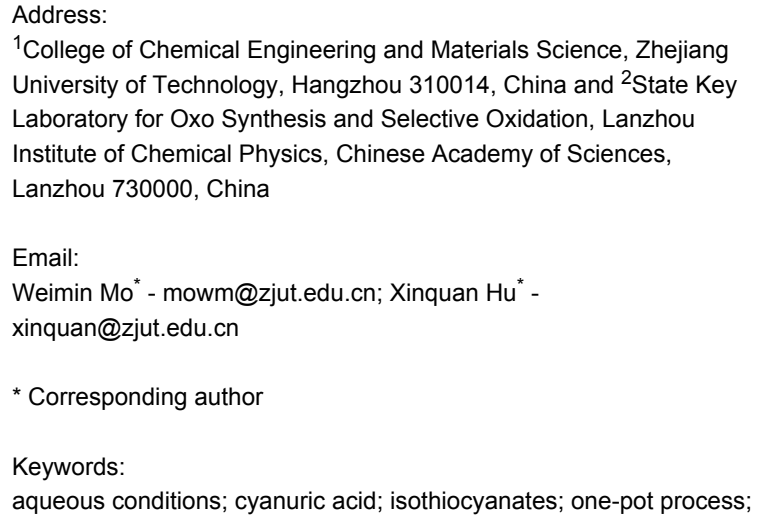

${ }^{1}$ College of Chemical Engineering and Materials Science, Zhejiang University of Technology, Hangzhou 310014, China and ${ }^{2}$ State Key Laboratory for Oxo Synthesis and Selective Oxidation, Lanzhou Institute of Chemical Physics, Chinese Academy of Sciences, Lanzhou 730000 , China

Email:

Weimin Mo* - mowm@zjut.edu.cn; Xinquan $\mathrm{Hu}^{*}$ -

xinquan@zjut.edu.cn

* Corresponding author

Keywords:

aqueous conditions; cyanuric acid; isothiocyanates; one-pot process;

Beilstein J. Org. Chem. 2012, 8, 61-70.

doi:10.3762/bjoc.8.6

Received: 04 November 2011

Accepted: 18 December 2011

Published: 10 January 2012

Associate Editor: D. Y.-K. Chen

(C) 2012 Sun et al; licensee Beilstein-Institut.

License and terms: see end of document. organic synthesis; primary amines

\begin{abstract}
A general and facile one-pot protocol for the preparation of a broad range of alkyl and aryl isothiocyanates has been developed from their corresponding primary amines under aqueous conditions. This synthetic process involves an in situ generation of a dithiocarbamate salt from the amine substrate by reacting with $\mathrm{CS}_{2}$ followed by elimination to form the isothiocyanate product with cyanuric acid as the desulfurylation reagent. The choice of solvent is of decisive importance for the successful formation of the dithiocarbamate salt particularly for highly electron-deficient substrates. This novel and economical method is suitable for scale-up activities.
\end{abstract}

\section{Introduction}

Isothiocyanates are a class of heteroallenic compounds which are abundant in many cruciferous vegetables. Recently, it has been found that naturally occurring isothiocyanates play a significant role in the cancer chemopreventive activity of these plant species [1,2], and thus, many of such analogues containing the isothiocyanate motif have been synthesized for potential medical applications [3-6]. Morevoer, isothiocyanates are pivotal intermediates in organic synthesis, especially in the synthesis of various heterocyclic compounds $[7,8]$ and unsymmetric thioureas [9-12]. Although many synthetic methods for the preparation of isothiocyanates have been reported to date [13-33], most methods suffer from the employment of highly 
toxic reagents such as thiophosgene and its analogs, the availability of non-commercialized reagents, or from a narrow substrate scope. Recently, a two-step approach, which was named reagent-promoted desulfurylation of dithiocarbamates strategy, has attracted much attention. In the context of this method, an amine is typically converted into a corresponding dithiocarbamate by reacting with $\mathrm{CS}_{2}$ in the presence of a base; and a subsequent desulfurylation affords the desired isothiocyanate with proper desulfurylation reagent. Although many desulfurylating reagents for this strategy were developed [34-59], most of them were efficient only for alkyl and electron-rich aryl isothiocyanates. Few efficient methods were reported for those substrates with highly electron-withdrawing groups (such as, $\mathrm{CF}_{3}, \mathrm{CN}, \mathrm{CH}_{3} \mathrm{CO}$ or $\mathrm{NO}_{2}$ ). Therefore, the development of a more efficient method for the synthesis of isothiocyanates particularly highly electron-deficient aryl isothiocyanates - is still a challenge in organic chemistry.

\section{Results and Discussion}

Previously, Furumoto reported the application of cyanuric chloride (2,4,6-trichloro-1,3,5-triazine, TCT) as a desulfurylation reagent in the synthesis of carbodiimides from thioureas under mild conditions [60]. In that reaction, the $S$-nucleophiles first reacted with TCT and then decomposed to release the product carbodiimides and by-product 2,4,6-trimercapto-1,3,5-triazine (TMT) [61]. Considering that TCT is an efficient desulfurylation reagent of thioureas to synthesize carbodiimides and that it is affordable in large scale, we speculated that it could also be effective and practical in the desulfurylation of dithiocarbamates to form isothiocyanates.

Our initial study started with aniline (1, Scheme 1$)$ to prepare phenyl isothiocyanate (4, Scheme 1$)$ via $N$-phenyl dithiocarbamate (2-1, Scheme 1) followed by desulfurylation with TCT.

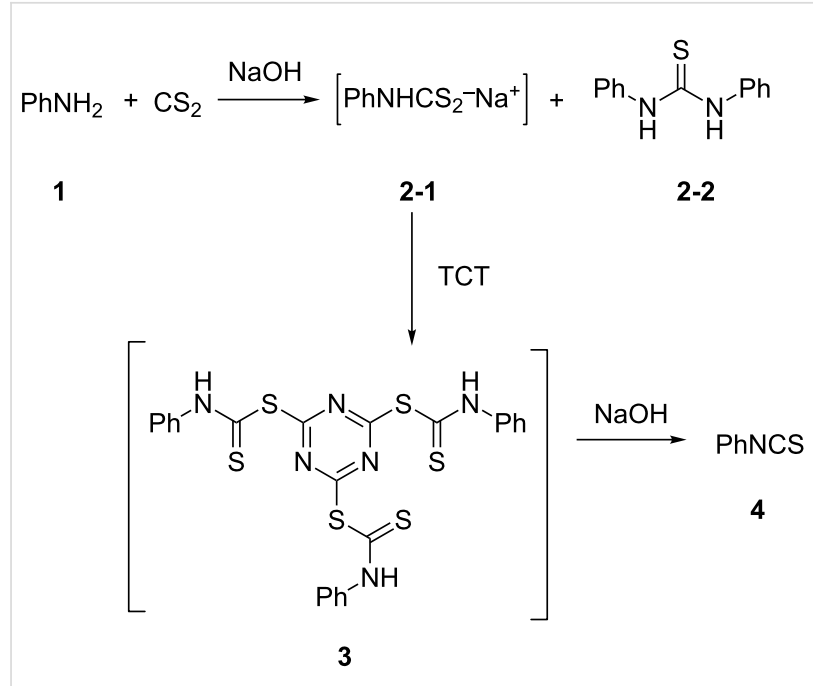

Scheme 1: The proposed process for the formation of $N$-phenyl isothiocyanate from aniline.

Because inorganic bases were more efficient during the conversion of arylamines to $\mathrm{N}$-aryl dithiocarbamates in aqueous systems [54-59], we chose inorganic bases to screen the optimal reaction conditions for the one-pot synthesis of 4 . Following the literature procedure, $N$-phenyl dithiocarbamate was generated by mixing aniline and 2.0 equiv of $\mathrm{CS}_{2}$ (based on aniline) in water with 1.0 equiv of $\mathrm{NaOH}$ at room temperature. After the complete disappearance of the aniline, the mixture was cooled to $0{ }^{\circ} \mathrm{C}$ and a solution of TCT ( 0.5 equiv) in $\mathrm{CH}_{2} \mathrm{Cl}_{2}$ was added. Then the biphasic mixture was stirred for $0.5 \mathrm{~h}$ and basified by addition of $6 \mathrm{~N} \mathrm{NaOH}$ to form a clear solution. A usual work-up afforded the phenyl isothiocyanate in $61 \%$ isolated yield along with a small amount of $N, N^{\prime}$-diphenylthiourea (Table 1 , entry 1). We proposed that the overall reaction proceeded as described in Scheme 1.

\begin{tabular}{|c|c|c|c|c|c|c|c|}
\hline entry & base & $\begin{array}{c}\text { aniline/CS } \mathrm{CS}_{2} / \text { base } \\
\text { (equiv) }\end{array}$ & time (h) & $\operatorname{conv}^{b}(\%)$ & $\begin{array}{l}\text { select }^{\mathrm{b}}(\%) \\
\mathbf{2 - 1 : 2 - 2}\end{array}$ & $\begin{array}{l}\mathrm{TCT}^{\mathrm{C}} \\
\text { (equiv) }\end{array}$ & $\begin{array}{c}\text { yield }^{\mathrm{d}} \\
(\%)\end{array}$ \\
\hline 1 & $\mathrm{NaOH}$ & $1: 2: 1$ & 3 & 94 & $63: 35$ & 0.5 & 61 \\
\hline 2 & $\mathrm{KOH}$ & $1: 2: 1$ & 3 & 93 & $72: 26$ & 0.5 & 63 \\
\hline 3 & $\mathrm{NH}_{4} \mathrm{OH}^{\mathrm{e}}$ & $1: 2: 1$ & 5 & 70 & $95: 2$ & - & - \\
\hline 4 & $\mathrm{Na}_{2} \mathrm{CO}_{3}$ & $1: 2: 1$ & 5 & 86 & $90: 6$ & - & - \\
\hline 5 & $\mathrm{NaHCO}_{3}$ & $1: 2: 1$ & 5 & 57 & $89: 2$ & - & - \\
\hline 6 & $\mathrm{~K}_{2} \mathrm{CO}_{3}$ & $1: 2: 1$ & 5 & 86 & $97: 1$ & - & - \\
\hline 7 & $\mathrm{~K}_{2} \mathrm{CO}_{3}$ & $1: 2: 2$ & 3 & $>99$ & 99:0 & 0.5 & 97 \\
\hline 8 & $\mathrm{~K}_{2} \mathrm{CO}_{3}$ & $1: 1.2: 2$ & 3 & $>99$ & 99:0 & $\begin{array}{c}0.5 \\
0.35\end{array}$ & $\begin{array}{l}98 \\
89\end{array}$ \\
\hline
\end{tabular}

aReaction conditions: $20 \mathrm{mmol}$ of aniline was used in the reaction of the formation of $\mathrm{N}$-phenyl dithiocarbamate at room temperature. The desulfurylation of in situ generated $\mathrm{N}$-phenyl dithiocarbamate was carried out by dropwise addition of a solution of $\mathrm{TCT}$ in $\mathrm{CH}_{2} \mathrm{Cl}_{2}$ at $0{ }^{\circ} \mathrm{C}$ and then, the mixture

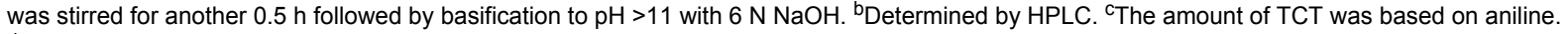
disolated yield. ${ }^{2} 28 \%$ aqueous $\mathrm{NH}_{4} \mathrm{OH}$ was used. 
The success observed in our preliminary study encouraged us to further optimize the conditions for better yields. Our immediate effort was to enhance the selectivity of $N$-phenyl dithiocarbamate over 1,3-diphenylthiourea (2-2) at the first stage. Although the formation of $\mathrm{N}$-phenyl dithiocarbamate by reaction of aniline and $\mathrm{CS}_{2}$ in the presence of inorganic base under aqueous conditions has already been reported, the conversion of aniline and the selection of $N$-phenyl dithiocarbamate have not been disclosed before. Thus, with the help of HPLC analysis, the selectivity of $N$-phenyl dithiocarbamate (2-1 in Scheme 1) was first studied by testing the base effect. The results of the selectivity of 2-1 with various bases are summarized in Table 1. As can be seen from Table 1, the conversion and the selectivity were influenced by the strength of the bases. When strong bases - such as $\mathrm{NaOH}$ and $\mathrm{KOH}$ - were employed, a significant amount of 1,3-diphenylthiourea (2-2) was formed; this resulted in the low selectivity for $\mathrm{N}$-phenyl dithiocarbamate (2-1) (Table 1 , entry 1 and 2) despite a high conversion observed for the anilines. When weaker bases - such as $\mathrm{NH}_{4} \mathrm{OH}, \mathrm{Na}_{2} \mathrm{CO}_{3}$ and $\mathrm{NaHCO}_{3}$ - were used, the selectivity of $\mathrm{N}$-phenyl dithiocarbamate was obviously improved but the conversion of aniline decreased even at elongated reaction time (Table 1, entries 3-5). A high selectivity for 2-1 (97:1) along with high conversion $(86 \%)$ was achieved (Table 1 , entry 6) when $\mathrm{K}_{2} \mathrm{CO}_{3}$ was used. When the reaction was carried out with 2 equiv of $\mathrm{K}_{2} \mathrm{CO}_{3}$, a complete conversion was observed. More importantly, the selectivity of 2-1 over 2-2 was almost exclusive (Table 1, entry 7). Further studies indicated that only a slight excess of $\mathrm{CS}_{2}$ is needed for a high conversion (Table 1, entry 8).

With an efficient method for the formation of 2-1 in hand, we then continued our research on the synthesis of phenyl isothiocyanate by the desulfurylation of 2-1 with TCT. We found out that the reaction between $\mathrm{N}$-phenyl dithiocarbamate and TCT proceeded rather fast, even at a lower temperature $\left(0{ }^{\circ} \mathrm{C}\right)$, and 0.5 equiv of TCT was proved to be necessary for a complete conversion of $\mathrm{N}$-phenyl dithiocarbamate. It turned out that the decomposition of the adduct formed between $\mathrm{N}$-phenyl dithiocarbamate and TCT to release phenyl isothiocyanate was incomplete under neutral to weak basic conditions. However, when the reaction mixture was basified to $\mathrm{pH}>11$ with $6 \mathrm{~N}$ $\mathrm{NaOH}$, a complete decomposition of the adduct was observed. Moreover, under this conditions, the by-product TMT was easily soluble in water to form a clear solution and thus, convenient to the layers separation during the workup. Under optimal conditions, an overall yield of phenyl isothiocyanate from aniline was obtained up to $98 \%$ (Table 1, entry 8). It should be noted that choosing $\mathrm{K}_{2} \mathrm{CO}_{3}$ as the reaction base was crucial. It was found out that only the potassium salt of $\mathrm{N}$-phenyl dithiocarbamate could form a clear aqueous solution, while the corresponding sodium salt was much less soluble and the ammonium salt was almost insoluble and difficult to stir. Although the isolation of intermediate 3 was not successful (Scheme 1), the fact that the formation of the side product TMT was observed strongly indicated the presence of this intermediacy.

To further study the substrate scope of this newly developed method, various amines were subjected to the treatment with $\mathrm{CS}_{2}$ in aqueous $\mathrm{K}_{2} \mathrm{CO}_{3}$ solution followed by desulfurylation with TCT under optimal conditions (1.2 equiv of $\mathrm{CS}_{2}, 2.0$ equiv of $\mathrm{K}_{2} \mathrm{CO}_{3}$ at room temperature, and 0.5 equiv of TCT in $\mathrm{CH}_{2} \mathrm{Cl}_{2}$ at $0{ }^{\circ} \mathrm{C}$ ). The results are summarized in Table 2. As can be seen from Table 2, all tested alkylamines and electron-rich arylamines afforded their corresponding isothiocyanates in excellent yields (Table 2, entries 1-13). Compared to arylamines, alkylamines can generally be converted into their corresponding dithiocarbamates in a relative short time. This rate difference could be originated from the different basicities and their differences in water solubility. Once the dithiocarbamate was generated, the desulfurylation step using TCT proceeded smoothly for all amines. The branched alkylamines, cyclic alkylamines and benzylamines showed similar activity as linear alkylamines (Table 2, entries 1-9). The relative low yields of isopropyl isothiocyanate and tert-butyl isothiocyanate were ascribed to their volatility loss associated with isolation (Table 2, entries 1 and 3). The substituent pattern on the phenyl ring of arylamines exhibited no different activity. This also illustrated the tolerance of some steric bulk in the synthesis of isothiocyanate (Table 2, entries 11-13). Under similar reaction conditions, we then tested some electron-deficient arylamines. The difficulty in the formation of their potassium salts of dithiocarbamate was not surprising. The reaction required a slightly higher temperature and a larger excess of $\mathrm{CS}_{2}$ to complete the conversion of substrate amines. For example, 3 equiv of $\mathrm{CS}_{2}$ was needed for the conversion of 4 -fluoroaniline at $40{ }^{\circ} \mathrm{C}$ in 12 h during the first step. When $N$-(4-fluorophenyl)dithiocarbamate was formed, 4-fluorophenyl isothiocyanate could be smoothly obtained in reasonable yield after treatment with TCT. However, under the same reaction conditions as 4-fluoroaniline, the reaction rate of 4-chloroaniline was much slower and a longer reaction time was needed. Increasing the amount of $\mathrm{CS}_{2}$ did not improve the conversion. Increasing the reaction temperature to $60{ }^{\circ} \mathrm{C}$ did improve the conversion of 4-chloroaniline but generated a lot of impurities. With 3 equiv of $\mathrm{CS}_{2}$ at $40{ }^{\circ} \mathrm{C}$ for $20 \mathrm{~h}$, about $80 \%$ conversion of 4-chloroaniline with $92 \%$ selectivity of dithiocarbamate was observed. However, only $70 \%$ yield of 4-chlorophenyl isothiocyanate was obtained (Table 2, entry 15). The more electron-deficient arylamines, such as 4-trifluoromethyl- and 4-cyanoaniline, failed to convert into their corresponding isothiocyanates when the same procedure as described for 4-chloroaniline was applied. 
Table 2: Preparation of isothiocyanates ${ }^{a}$

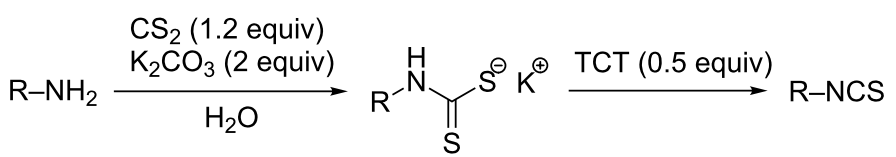

\begin{tabular}{|c|c|c|c|c|}
\hline entry & substrate & product & time $^{b}(h)$ & yield ${ }^{c}(\%)$ \\
\hline 1 & & & 1 & 85 \\
\hline 2 & & & 1 & 94 \\
\hline 3 & & & 1 & 80 \\
\hline 4 & & & 1 & 95 \\
\hline 5 & & & 1 & 98 \\
\hline 6 & & & 1 & 95 \\
\hline 7 & & & 1 & 99 \\
\hline 8 & & & 1 & 99 \\
\hline 9 & & & 3 & $98(94)$ \\
\hline 10 & & & 3 & 86 \\
\hline 11 & & & 3 & 93 \\
\hline 12 & & & 3 & 95 \\
\hline 13 & & & 3 & 98 \\
\hline 14 & & & 12 & $81^{d}$ \\
\hline 15 & 15 & & 20 & $70^{d}$ \\
\hline
\end{tabular}

aReaction conditions: $20 \mathrm{mmol}$ of amine substrate, $24 \mathrm{mmol}$ of $\mathrm{CS}_{2}, 40 \mathrm{mmol}$ of $\mathrm{K}_{2} \mathrm{CO}_{3}$, room temperature. HPLC monitored the conversion. After the amine was totally consumed, the mixture was cooled to $0{ }^{\circ} \mathrm{C}$, and $10 \mathrm{mmol}$ of TCT in $\mathrm{CH}_{2} \mathrm{Cl}_{2}$ was added dropwise. The mixture was stirred for another $0.5 \mathrm{~h}$ and basified to $\mathrm{pH}>11$ with $6 \mathrm{~N} \mathrm{NaOH}$. ${ }^{\mathrm{b}}$ The reaction time for the first step. ${ }^{\mathrm{C}}$ Isolated yield. Data in the parenthesis is the isolated yield in 1 -mol scale. ${ }^{\mathrm{d}} 3.0$ equiv of $\mathrm{CS}_{2}$ was used and the reaction temperature was $40^{\circ} \mathrm{C}$.

Moreover, to evaluate the procedure for the potential scaling-up capability, we used aniline as test substrate to scale up the synthesis in $1.0 \mathrm{~mol}$ scale. It became clear that the desired phenyl isothiocyanate could be conveniently isolated via vacuum distillation (Table 2, entry 9). This experiment demonstrated its potential for a larger-scale application. 
The inefficiency observed for the highly electron-deficient arylamines drove us to further optimize the process. We speculated that the inefficiency for those strongly electron-deficient arylamines could be ascribed to the difficulty in the generation of dithiocarbamates between amines and $\mathrm{CS}_{2}$ in aqueous $\mathrm{K}_{2} \mathrm{CO}_{3}$ solution. This prompted us to seek new reaction conditions. It was reported that $\mathrm{C}_{2} \mathrm{H}_{5} \mathrm{OH}$ was a beneficial solvent in the conversion of electron-deficient arylamines to their corresponding dithiocarbamates with concentrated $\mathrm{NH}_{4} \mathrm{OH}$ [54]. The effect of $\mathrm{C}_{2} \mathrm{H}_{5} \mathrm{OH}$ in reaction media might facilitate the solubility of arylamines in water and thus, accelerate the reaction. Unfortunately, we found that $\mathrm{CS}_{2}$ would react with $\mathrm{C}_{2} \mathrm{H}_{5} \mathrm{OH}$ to form insoluble solid when it was charged into the reaction mixture. This solid was separated and confirmed to be potassium ethylxanthate formed between $\mathrm{CS}_{2}$ and $\mathrm{C}_{2} \mathrm{H}_{5} \mathrm{OH}$ in aqueous basic solution [62]. On the other hand, much better results were observed when acetonitrile, DMF or DMAc was employed. For example, with 4-chloroaniline as the substrate (Table 3), the results showed that the reaction rate of 4-chloroaniline with $\mathrm{CS}_{2}$ in the aqueous $\mathrm{K}_{2} \mathrm{CO}_{3}$ solution was significantly improved with acetonitrile, DMF or DMAc, and best conversion was obtained with DMF as co-solvent (Table 3). The optimized result showed that a solvent mixture of DMF/water (1:4) is suitable for electron-deficient arylamines (Table 3 , entry 5).

Under optimal conditions, various electron-deficient arylamines were converted into the desired isothiocyanates in high yield and the results were listed in Table 4. With the help of DMF, more $\mathrm{CS}_{2}$ and longer reaction time, those strong electron-deficient arylamines, for examples, $\mathrm{CF}_{3}, \mathrm{CN}, \mathrm{CH}_{3} \mathrm{CO}$-substituted arylamines, could be also converted into their dithiocarbamates, which could smoothly afford high yield of their corresponding isothiocyanates by further treatment with TCT (Table 4, entries 5-7). To our surprise, in the case of 4-nitroaniline as the substrate, only $13 \%$ of 4-nitrophenyl isothiocyanate was obtained along with up to $50 \%$ of 1,4-diisothiocyanatobenzene (Table 4 , entry 8). This probably resulted from the partial reduction of 4-nitroaniline to 1,4-diaminobenzene by $\mathrm{CS}_{2}$ in aqueous $\mathrm{K}_{2} \mathrm{CO}_{3}$ solution.

\section{Conclusion}

In summary, we have successfully developed a facile and general method to synthesize isothiocyanates from amines. In the context of this method, the amines reacted with $\mathrm{CS}_{2}$ in aqueous $\mathrm{K}_{2} \mathrm{CO}_{3}$ solutions to afford dithiocarbamate intermediates, which were further desulfurylized with TCT at $0{ }^{\circ} \mathrm{C}$ to provide the corresponding isothiocyanates. The newly developed method could convert a wide range of primary alkyl and arylamines into their corresponding isothiocyanates in excellent yields and provides promise for further scale-up activities. Morevover, this method is advantageous over many other methods for the synthesis of highly electron-deficient aromatic isothiocyanates.

\section{Experimental General}

All solvents and reagents were purchased from commercial sources and used without further purification. Melting points were measured without correction. Proton NMR spectra were recorded on a $500 \mathrm{MHz}$ spectrometer in $\mathrm{CDCl}_{3}$ with tetramethylsilane (TMS) as internal standard. IR spectra were performed on a FTIR instrument. GC-MS analyses were

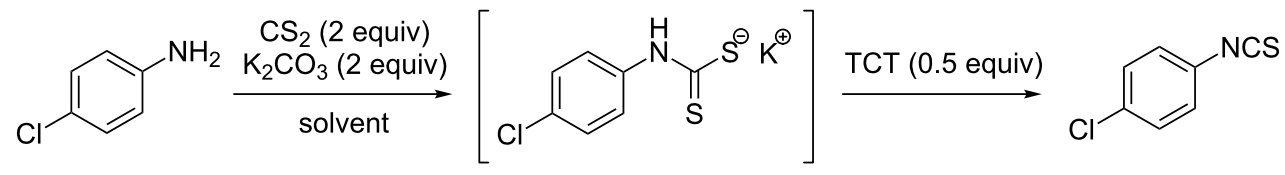

\begin{tabular}{ccccc}
\hline entry & solvent $(\mathrm{v} / \mathrm{v})^{\mathrm{b}}$ & time $(\mathrm{h})^{\mathrm{c}}$ & ${\text { conversion }(\%)^{\mathrm{d}}}^{\left.\text {yield }^{\mathrm{C}} \%\right)^{\mathrm{e}}}$ \\
\hline 1 & $\mathrm{H}_{2} \mathrm{O}$ & 20 & 56 & 50 \\
2 & $\mathrm{CH}_{3} \mathrm{CN}: \mathrm{H}_{2} \mathrm{O}(1: 2)$ & 20 & 80 & 64 \\
3 & $\mathrm{DMAc}: \mathrm{H}_{2} \mathrm{O}(1: 2)$ & 6 & 91 & 86 \\
4 & $\mathrm{DMF}: \mathrm{H}_{2} \mathrm{O}(1: 2)$ & 6 & 98 & 91 \\
5 & $\mathrm{DMF}: \mathrm{H}_{2} \mathrm{O}(1: 4)$ & 6 & 98 & 92 \\
6 & $\mathrm{DMF}: \mathrm{H}_{2} \mathrm{O}(1: 6)$ & 10 & 90 & 80 \\
\hline
\end{tabular}

aReaction conditions: $20 \mathrm{mmol}$ of 4-chloroaniline was used in the reaction of the formation of $\mathrm{N}$-(4-chlorophenyl)dithiocarbamate at $40{ }^{\circ} \mathrm{C}$. The desulfurylation of in situ generated $\mathrm{N}$-(4-chlorophenyl)dithiocarbamate was carried out by dropwise addition of a solution of $\mathrm{TCT}$ in $\mathrm{CH}_{2} \mathrm{Cl}_{2}$ at $0{ }^{\circ} \mathrm{C}$ and then the mixture was stirred another $0.5 \mathrm{~h}$ followed by basification to $\mathrm{pH}>11$ with $6 \mathrm{~N} \mathrm{NaOH}$. DMAc $=N, \mathrm{~N}$-dimethyl acetamide. ${ }^{\text {b } 20 ~ m L ~ o f ~} \mathrm{H}_{2} \mathrm{O}$ used. ${ }^{\mathrm{C}}$ The reaction time for the conversion of 4 -chloroaniline to potassium $\mathrm{N}$-(4-chlorophenyl)dithiocarbamate. ${ }^{\mathrm{d}}$ Determined by HPLC. ${ }^{\mathrm{e}}$ Isolated yield. 
Table 4: Preparation of electron-deficient aryl isothiocyanates ${ }^{a}$.

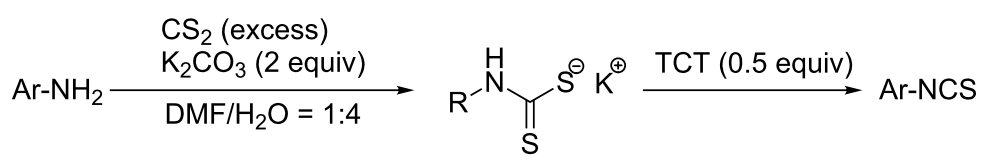

Entry ${\text { Time }{ }^{\mathrm{b}}(\mathrm{h})}^{\text {Yield }^{\mathrm{c}}(\%)}$

aReaction conditions: The substrate $(20 \mathrm{mmol})$ was treated with excess of $\mathrm{CS}_{2}$ and 2 equiv of $\mathrm{K}_{2} \mathrm{CO}_{3}$ in the mixture of $5 \mathrm{~mL}$ of $\mathrm{DMF}$ and $20 \mathrm{~mL}$ of $\mathrm{H}_{2} \mathrm{O}$ at $40{ }^{\circ} \mathrm{C}$. After the conversion of the substrate was complete, the mixture was cooled to $0{ }^{\circ} \mathrm{C}$ and $10 \mathrm{mmol}$ of $\mathrm{TCT}_{\text {in }} \mathrm{CH}_{2} \mathrm{Cl}_{2}$ was added drop-

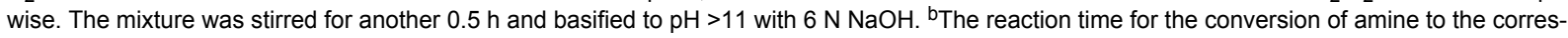
ponding dithiocarbamate. ${ }^{\mathrm{C}}$ Isolated yield.

performed in EI mode. HPLC analyses were performed using a Atlantis ODS column $(150 \times 4.6 \mathrm{~mm}$ (i.d.), $3.5 \mu \mathrm{m})$ with a UV detector $(280 \mathrm{~nm})$ at room temperature and mobile phase $(60: 40$ $\mathrm{CH}_{3} \mathrm{CN} / 5 \mathrm{mmol} / \mathrm{L} \mathrm{K}_{2} \mathrm{HPO}_{4}$ water solution) with a flow rate of $0.8 \mathrm{~mL} / \mathrm{min}$. GC analyses were performed with a FID detector using a HP-5 capillary column $(30 \mathrm{~m} \times 0.25 \mathrm{~mm}$ (i.d.), $0.25 \mu \mathrm{m}$ film thickness). The flow rate of carrier gas $\left(\mathrm{N}_{2}\right)$ was $1.0 \mathrm{~mL} /$ min with a split ratio of 50:1. The column temperature was increased from an initial temperature of 100 to $280^{\circ} \mathrm{C}$ at $10^{\circ} \mathrm{C} /$ min and maintained at this temperature for $10 \mathrm{~min}$. The FID detector temperature was kept at $280{ }^{\circ} \mathrm{C}$. All operations were carried out under atmospheric conditions and all synthesized isothiocyanates were stable under the operational conditions.

\section{Typical procedure for the preparation of alkyl and} aryl isothiocyanates

To a mixture of amine $(20 \mathrm{mmol})$ and $\mathrm{K}_{2} \mathrm{CO}_{3}(5.52 \mathrm{~g}, 40$ $\mathrm{mmol})$ in $20 \mathrm{~mL}$ of water $1.82 \mathrm{~g}$ of $\mathrm{CS}_{2}(24 \mathrm{mmol})$ was added dropwise in a period of 20-30 $\mathrm{min}$ at room temperature. After the addition was complete, the mixture was stirred for several hours until complete conversion was determined by HPLC (arylamine) or GC (alkylamine). Then, the reaction mixture was cooled to $0{ }^{\circ} \mathrm{C}$ and a solution of $1.85 \mathrm{~g}$ of TCT $(10 \mathrm{mmol})$ in 15 $\mathrm{mL}$ of $\mathrm{CH}_{2} \mathrm{Cl}_{2}$ was added dropwise. After the addition was complete, the mixture was stirred for another $0.5 \mathrm{~h}$ to finish the reaction. The reaction mixture was then basified to $\mathrm{pH}>11$ with $6 \mathrm{~N} \mathrm{NaOH}$ to obtain a clear solution. The organic layer was sep- 
arated and the aqueous phase was extracted with $\mathrm{CH}_{2} \mathrm{Cl}_{2}(2 \times$ $10 \mathrm{~mL}$ ). The combined organic layers were dried over anhydrous $\mathrm{Na}_{2} \mathrm{SO}_{4}$, filtered and the solvent was removed in vacuo. The residual was purified by flash chromatography through a short silica column using petroleum ether as eluent.

Isopropyl isothiocyanate (CAS No: 2253-73-8, Table 2, entry 1): Yield: $85 \%$; colorless oil; IR (neat): $2079 \mathrm{~cm}^{-1}$; ${ }^{1} \mathrm{H}$ NMR $\left(\mathrm{CDCl}_{3}\right) \delta 1.37(\mathrm{~d}, J=7.0 \mathrm{~Hz}, 6 \mathrm{H}), 3.88-3.95(\mathrm{~m}$, $1 \mathrm{H})$; GC-EIMS m/z: $101\left[\mathrm{M}^{+}, 100 \%\right]$.

n-Butyl isothiocyanate (CAS No: 592-82-5, Table 2, entry 2): Yield: 94\%; colorless oil; IR (neat): $2099 \mathrm{~cm}^{-1}$; ${ }^{1} \mathrm{H}$ NMR $\left(\mathrm{CDCl}_{3}\right) \delta 0.94-0.97(\mathrm{t}, J=7.0 \mathrm{~Hz}, 3 \mathrm{H}), 1.42-1.50(\mathrm{~m}, 2 \mathrm{H})$, $1.66-1.72(\mathrm{~m}, 2 \mathrm{H}), 3.53(\mathrm{t}, J=6.5 \mathrm{~Hz}, 2 \mathrm{H})$; GC-EIMS $m / z: 115$ $\left[\mathrm{M}^{+}, 100 \%\right]$.

tert-Butyl isothiocyanate (CAS No: 590-42-1, Table 2, entry 3): Yield: $80 \%$; colorless oil; IR (neat): $2074 \mathrm{~cm}^{-1}$; ${ }^{1} \mathrm{H}$ NMR $\left(\mathrm{CDCl}_{3}\right) \delta 1.44$ (s, 9H); GC-EIMS m/z: $115\left[\mathrm{M}^{+}, 100 \%\right]$.

n-Octyl isothiocyanate (CAS No: 4430-45-9, Table 2, entry 4): Yield: 95\%; colorless oil; IR (neat): $2102 \mathrm{~cm}^{-1}$; ${ }^{1} \mathrm{H}$ NMR $\left(\mathrm{CDCl}_{3}\right) \delta 0.89(\mathrm{t}, J=7.0 \mathrm{~Hz}, 3 \mathrm{H}), 1.28-1.32(\mathrm{~m}, 8 \mathrm{H})$, $1.39-1.42(\mathrm{~m}, 2 \mathrm{H}), 1.67-1.72(\mathrm{~m}, 2 \mathrm{H}), 3.51$ (t, $J=7.0 \mathrm{~Hz}, 2 \mathrm{H})$; GC-EIMS $m / z$ : $171\left[\mathrm{M}^{+}, 0 \%\right], 115$ (100\%).

2-Ethyl-1-hexyl isothiocyanate (CAS No: 21663-56-9, Table 2, entry 5): Yield: 98\%; colorless oil; IR (neat): 2095 $\mathrm{cm}^{-1} ;{ }^{1} \mathrm{H}$ NMR $\left(\mathrm{CDCl}_{3}\right) \delta 0.90-0.93(\mathrm{~m}, 6 \mathrm{H}), 1.25-1.44(\mathrm{~m}$, $8 \mathrm{H}), 1.56-1.61(\mathrm{~m}, 1 \mathrm{H}), 3.47-3.49(\mathrm{~m}, 2 \mathrm{H})$; GC-EIMS $m / z$ : $171\left[\mathrm{M}^{+}, 4 \%\right], 57(100 \%)$.

Cyclohexyl isothiocyanate (CAS No: 1122-82-3, Table 2, entry 6): Yield: 95\%; colorless oil; IR (neat): $2103 \mathrm{~cm}^{-1}$; ${ }^{1} \mathrm{H} \mathrm{NMR}\left(\mathrm{CDCl}_{3}\right) \delta 1.38-1.90(\mathrm{~m}, 10 \mathrm{H}), 3.67-3.71(\mathrm{~m}, 1 \mathrm{H})$; GC-EIMS $m / z: 141\left[\mathrm{M}^{+}, 90 \%\right], 55$ (100\%).

Benzyl isothiocyanate (CAS No: 622-78-6, Table 2, entry 7): Yield: 99\%; colorless oil; IR (neat): $2091 \mathrm{~cm}^{-1}$; ${ }^{1} \mathrm{H}$ NMR $\left(\mathrm{CDCl}_{3}\right) \delta 4.71(\mathrm{~s}, 2 \mathrm{H}), 7.31-7.41(\mathrm{~m}, 5 \mathrm{H})$; GC-EIMS m/z: 149 $\left[\mathrm{M}^{+}, 30 \%\right], 91(100 \%)$.

1-Phenylethyl isothiocyanate (CAS No: 4478-92-6, Table 2, entry 8): Yield: 99\%; colorless oil; IR (neat): $2090 \mathrm{~cm}^{-1}$; ${ }^{1} \mathrm{H} \mathrm{NMR}\left(\mathrm{CDCl}_{3}\right) \delta 1.67(\mathrm{~d}, J=6.5 \mathrm{~Hz}, 3 \mathrm{H}), 4.91(\mathrm{q}, J=6.5$ $\mathrm{Hz}, 1 \mathrm{H}), 7.31-7.40(\mathrm{~m}, 5 \mathrm{H})$; GC-EIMS m/z: 163 [M $\left.\mathrm{M}^{+}, 6 \%\right], 105$ $(100 \%)$.

Phenyl isothiocyanate (CAS No: 103-72-0, Table 2, entry 9): Yield: 98\%; colorless oil; IR (neat): $2079 \mathrm{~cm}^{-1}$;
${ }^{1} \mathrm{H}$ NMR $\left(\mathrm{CDCl}_{3}\right) \delta$ 7.20-7.35 (m, 5H); GC-EIMS m/z: 135 $\left[\mathrm{M}^{+}, 100 \%\right]$.

4-Methoxyphenyl isothiocyanate (CAS No: 2284-20-0, Table 2, entry 10): Yield: 86\%; colorless oil; IR (neat): 2109 $\mathrm{cm}^{-1} ;{ }^{1} \mathrm{H} \mathrm{NMR}\left(\mathrm{CDCl}_{3}\right) \delta 3.81(\mathrm{~s}, 3 \mathrm{H}), 6.84-7.18(\mathrm{~m}, 4 \mathrm{H})$; GC-EIMS $m / z: 165\left[\mathrm{M}^{+}, 100 \%\right]$.

4-Methylphenyl isothiocyanate (CAS No: 622-59-3, Table 2, entry 11): Yield: 93\%; colorless oil; IR (neat): $2100 \mathrm{~cm}^{-1}$; ${ }^{1} \mathrm{H}$ NMR $\left(\mathrm{CDCl}_{3}\right) \delta 2.34$ (s, 3H), 7.10-7.15 (m, 4H); GC-EIMS $m / z: 149\left[\mathrm{M}^{+}, 100 \%\right]$.

2-Methylphenyl isothiocyanate (CAS No: 614-69-7, Table 2, entry 12): Yield: $95 \%$; colorless oil; IR (neat): $2083 \mathrm{~cm}^{-1}$; ${ }^{1} \mathrm{H} \mathrm{NMR}\left(\mathrm{CDCl}_{3}\right) \delta 2.38(\mathrm{~s}, 3 \mathrm{H}), 7.16-7.22(\mathrm{~m}, 4 \mathrm{H})$; GC-EIMS $m / z: 149\left[\mathrm{M}^{+}, 100 \%\right]$.

3-Methylphenyl isothiocyanate (CAS No: 621-30-7, Table 2, entry 13): Yield: 98\%; colorless oil; IR (neat): $2106 \mathrm{~cm}^{-1}$; ${ }^{1} \mathrm{H}$ NMR $\left(\mathrm{CDCl}_{3}\right) \delta 2.34$ (s, 3H), 7.02-7.24 (m, 4H); GC-EIMS $m / z: 149\left[\mathrm{M}^{+}, 100 \%\right]$.

\section{Synthetic procedure for phenyl isothiocyanate in 1-mol scale}

Into a 2-L jacketed flask, $91.2 \mathrm{~g}$ of $\mathrm{CS}_{2}(1.2 \mathrm{~mol})$ was dropwise added to a mixture of aniline $(93.0 \mathrm{~g}, 1.0 \mathrm{~mol})$ and $\mathrm{K}_{2} \mathrm{CO}_{3}$ (276.0 g, $2.0 \mathrm{~mol})$ in $700 \mathrm{~mL}$ of water at room temperature within a period of $2.5 \mathrm{~h}$. After the addition was complete, the mixture was stirred another $2 \mathrm{~h}$. Then, the mixture was cooled to $0{ }^{\circ} \mathrm{C}$, and a solution of $92.3 \mathrm{~g}$ of TCT $(0.5 \mathrm{~mol})$ in $450 \mathrm{~mL}$ of $\mathrm{CH}_{2} \mathrm{Cl}_{2}$ was dropwise added within $4 \mathrm{~h}$. After the addition was complete, the mixture was stirred another $1 \mathrm{~h}$ to complete the conversion. The resulting mixture was basified to $\mathrm{pH}>11$ with $250 \mathrm{~mL}$ of $6 \mathrm{~N} \mathrm{NaOH}$ and yielded a clear solution. The organic layer was separated and the aqueous layer was extracted with $150 \mathrm{~mL}$ of $\mathrm{CH}_{2} \mathrm{Cl}_{2}$. The combined organic layers were dried over anhydrous $\mathrm{Na}_{2} \mathrm{SO}_{4}$, filtered, and the solvent of filtrate was removed via distillation under atmospheric pressure with a $25-\mathrm{cm}$ Vigreux column. The residue was vacuum distilled and the desired product fraction was collected at $72-74{ }^{\circ} \mathrm{C} / 1 \mathrm{mmHg}$. Finally, $127.0 \mathrm{~g}$ of colorless liquid (94\%) was obtained.

\section{Typical procedure for the preparation of electron- deficient aryl isothiocyanates}

A certain amount of $\mathrm{CS}_{2}$ and arylamine $(20 \mathrm{mmol})$ was added to a solution of $\mathrm{K}_{2} \mathrm{CO}_{3}(5.52 \mathrm{~g}, 40 \mathrm{mmol})$ in $20 \mathrm{~mL}$ of water and $5 \mathrm{~mL}$ of DMF. The mixture was warmed to $40{ }^{\circ} \mathrm{C}$ for several hours to a constant conversion based on HPLC determination. The following operation was the same as the experimental procedure described above. 
4-Fluorophenyl isothiocyanate (CAS No: 1544-68-9, Table 4, entry 1): Yield: 94\%; colorless oil; IR (neat): $2079 \mathrm{~cm}^{-1}$; ${ }^{1} \mathrm{H}$ NMR $\left(\mathrm{CDCl}_{3}\right) \delta$ 7.04-7.08 (m, 2H), 7.21-7.24 (m, 2H); GC-EIMS $m / z: 153\left[\mathrm{M}^{+}, 100 \%\right]$.

4-Chlorophenyl isothiocyanate (CAS No: 2131-55-7, Table 4, entry 2): Yield: $92 \%$; white solid; $\mathrm{mp} 45-46{ }^{\circ} \mathrm{C}$ (lit. [57]: $\mathrm{mp}$ 44-45 $\left.{ }^{\circ} \mathrm{C}\right)$; IR (KBr): $2037 \mathrm{~cm}^{-1} ;{ }^{1} \mathrm{H}$ NMR $\left(\mathrm{CDCl}_{3}\right) \delta$ 7.15-7.18 (m, 2H), 7.31-7.33 (m, 2H); GC-EIMS m/z: 169 $\left[\mathrm{M}^{+}, 100 \%\right], 171[\mathrm{M}+2,44 \%]$.

2-Chlorophenyl isothiocyanate (CAS No: 2740-81-0, Table 4, entry 3): Yield: 90\%; colorless oil; IR (neat): $2075 \mathrm{~cm}^{-1}$; ${ }^{1} \mathrm{H}$ NMR $\left(\mathrm{CDCl}_{3}\right) \delta$ 7.19-7.25 (m, 3H), 7.41-7.43 (m, 1H); GC-EIMS $m / z$ : $169\left[\mathrm{M}^{+}, 100 \%\right], 171[\mathrm{M}+2,37 \%]$.

3-Chlorophenyl isothiocyanate (CAS No: 2392-68-9, Table 4, entry 4): Yield: $89 \%$; colorless oil; IR (neat): $2097 \mathrm{~cm}^{-1}$; ${ }^{1} \mathrm{H}$ NMR $\left(\mathrm{CDCl}_{3}\right) \delta$ 7.10-7.13 (m, 1H), 7.22-7.30 (m, 3H); GC-EIMS $m / z$ : $169\left[\mathrm{M}^{+}, 100 \%\right], 171[\mathrm{M}+2,34 \%]$.

4-Trifluoromethylphenyl isothiocyanate (CAS No: 1645-654, Table 4, entry 5): Yield: $89 \%$; White solid; mp 40-41 ${ }^{\circ} \mathrm{C}$ (lit. [52]: mp $\left.43{ }^{\circ} \mathrm{C}\right)$; IR (KBr): $2091 \mathrm{~cm}^{-1} ;{ }^{1} \mathrm{H} \mathrm{NMR}\left(\mathrm{CDCl}_{3}\right) \delta$ 7.31-7.34 (m, 2H), 7.62-7.63 (m, 2H); GC-EIMS $m / z: 203$ $\left[\mathrm{M}^{+}, 100 \%\right]$.

4-Acetophenyl isothiocyanate (CAS No: 2131-57-9, Table 4, entry 6): Yield: $86 \%$; white solid; $\mathrm{mp} 73-74{ }^{\circ} \mathrm{C}$ (lit. [63]: $\mathrm{mp}$ $\left.75-76{ }^{\circ} \mathrm{C}\right)$; IR (KBr): $2125,1680 \mathrm{~cm}^{-1} ;{ }^{1} \mathrm{H} \mathrm{NMR}\left(\mathrm{CDCl}_{3}\right) \delta$ $2.61(\mathrm{~s}, 3 \mathrm{H}), 7.30-7.32(\mathrm{~m}, 2 \mathrm{H}), 7.96-7.98$ (m, 2H); GC-EIMS $\mathrm{m} / \mathrm{z}: 177\left[\mathrm{M}^{+}, 70 \%\right], 162(100 \%)$.

4-Cyanophenyl isothiocyanate (CAS No: 2719-32-6, Table 4, entry 7): Yield: $91 \%$; white solid; $\mathrm{mp} 121-122{ }^{\circ} \mathrm{C}$ (lit. [63]: $\mathrm{mp}$ 119-120 $\left.{ }^{\circ} \mathrm{C}\right)$; IR (KBr): $2138 \mathrm{~cm}^{-1} ;{ }^{1} \mathrm{H} \mathrm{NMR}\left(\mathrm{CDCl}_{3}\right) \delta$ 7.30-7.32 (m, 2H), 7.65-7.67 (m, 2H); GC-EIMS $m / z: 160$ $\left[\mathrm{M}^{+}, 100 \%\right]$.

4-Nitrophenyl isothiocyanate (CAS No: 2131-61-5, Table 4, entry 8): Yield: $13 \%$; white solid; $\mathrm{mp} 107-108^{\circ} \mathrm{C}$ (lit. [63]: $\mathrm{mp}$ 108-110 $\left.{ }^{\circ} \mathrm{C}\right)$; IR (KBr): $2120 \mathrm{~cm}^{-1} ;{ }^{1} \mathrm{H}$ NMR $\left(\mathrm{CDCl}_{3}\right) \delta$ $7.36-7.38(\mathrm{~m}, 2 \mathrm{H}), 8.26-8.27(\mathrm{~m}, 2 \mathrm{H})$; GC-EIMS $m / z: 180$ $\left[\mathrm{M}^{+}, 100 \%\right]$.

1,4-Diisothiocyanatobenzene (CAS No: 4044-65-9, Table 4, entry 8): Yield: $50 \%$; white solid; mp 129-130 ${ }^{\circ} \mathrm{C}$ (lit. [64]: mp $132{ }^{\circ} \mathrm{C}$ ); IR (KBr): $2072 \mathrm{~cm}^{-1} ;{ }^{1} \mathrm{H} \mathrm{NMR}\left(\mathrm{CDCl}_{3}\right) \delta 7.22$ (s, 4H); GC-EIMS m/z: $192\left[\mathrm{M}^{+}, 100 \%\right]$.

\section{Supporting Information}

\section{Supporting Information File 1}

Proton NMR and GC-MS spectra.

[http://www.beilstein-journals.org/bjoc/content/

supplementary/1860-5397-8-6-S1.pdf]

\section{Acknowledgements}

The authors gratefully acknowledge the financial support of the National Natural Science Foundation of China (NSFC, 20772111, 20876149), the project of Science and Technology Department of Zhejiang Province (2009C21013) and the Natural Science Foundation of Zhejiang Province (Y407193). Hu would like to thank Dr. Tony Y. Zhang and Prof. Wenjun Tang for their helpful discussions and comments.

\section{References}

1. Fahey, J. W.; Zalcmann, A. T.; Talalay, P. Phytochemistry 2001, 56, 5-51. doi:10.1016/S0031-9422(00)00316-2

2. Nakamura, Y.; Miyoshi, N. Biosci., Biotechnol., Biochem. 2010, 74, 242-255. doi:10.1271/bbb.90731

3. Pedras, M. S. C.; Zheng, Q.-A.; Gadagi, R. S. Chem. Commun. 2007, 368-370. doi:10.1039/b615424g

4. Munday, R.; Zhang, Y.; Munday, C. M.; Bapardekar, M. V.; Paonessa, J. D. Pharm. Res. 2008, 25, 2164-2170. doi:10.1007/s11095-008-9595-2

5. Tian, X.; Huters, A. D.; Douglas, C. J.; Garg, N. K. Org. Lett. 2009, 11, 2349-2351. doi:10.1021/ol9007684

6. Adsule, S.; Banerjee, S.; Ahmed, F.; Padhye, S.; Sarkar, F. H. Bioorg. Med. Chem. Lett. 2010, 20, 1247-1251. doi:10.1016/j.bmcl.2009.11.128

7. Mukerjee, A. K.; Ashare, R. Chem. Rev. 1991, 91, 1-24. doi:10.1021/cr00001a001

8. Sommen, G. Synlett 2004, 1323-1324. doi:10.1055/s-2004-825608

9. Li, J.; Tan, Z.; Tang, S.; Hewlett, I.; Pang, R.; He, M.; He, S.; Tian, B.; Chen, K.; Yang, M. Bioorg. Med. Chem. 2009, 17, 3177-3188. doi:10.1016/j.bmc.2009.02.051

10. Kang, I.-J.; Wang, L.-W.; Yeh, T.-K.; Lee, C.-C.; Lee, Y.-C.; Hsu, S.-J.; Wu, Y.-S.; Wang, J.-C.; Chao, Y.-S.; Yueh, A.; Chern, J.-H. Bioorg. Med. Chem. 2010, 18, 6414-6421. doi:10.1016/j.bmc.2010.07.002

11. Peng, H.; Liang, Y.; Chen, L.; Fu, L.; Wang, H.; He, H. Bioorg. Med. Chem. Lett. 2011, 21, 1102-1104. doi:10.1016/j.bmcl.2010.12.130

12. Doyle, A. G.; Jacobsen, E. N. Chem. Rev. 2007, 107, 5713-5743. doi:10.1021/cr068373r

13. Toshimitsu, A.; Uemura, S.; Okano, M.; Watanabe, N. J. Org. Chem. 1983, 48, 5246-5251. doi:10.1021/jo00174a018

14. Albanese, D.; Penso, M. Synthesis 1991, 1001-1002. doi:10.1055/s-1991-26629

15. Shan, W. G.; Bian, G. F.; Su, W. K.; Liang, X. R. Org. Prep. Proced. Int. 2004, 36, 283-286. doi:10.1080/00304940409355967

16. Kim, J. N.; Ryu, E. K. Tetrahedron Lett. 1993, 34, 8283-8284. doi:10.1016/S0040-4039(00)61411-9 
17. Kim, J. N.; Jung, K. S.; Lee, H. J.; Son, J. S. Tetrahedron Lett. 1997, 38, 1597-1598. doi:10.1016/S0040-4039(97)00121-4

18. Adam, W.; Bargon, R. M.; Bosio, S. G.; Schenk, W. A.; Stalke, D. J. Org. Chem. 2002, 67, 7037-7041. doi:10.1021/jo026042i

19. Arisawa, M.; Ashikawa, M.; Suwa, A.; Yamaguchi, M. Tetrahedron Lett. 2005, 46, 1727-1729. doi:10.1016/j.tetlet.2005.01.069

20. Valette, L.; Poulain, S.; Fernandez, X.; Lizzani-Cuvelier, L. J. Sulfur Chem. 2005, 26, 155-161. doi:10.1080/17415990500070144

21. Isoda, T.; Hayashi, K.; Tamai, S.; Kumagai, T.; Nagao, Y. Chem. Pharm. Bull. 2006, 54, 1616-1619. doi:10.1248/cpb.54.1616

22. Zhong, B.; Al-Awar, R. S.; Shih, C.; Grimes, J. H., Jr.; Vieth, M.; Hamdouchi, C. Tetrahedron Lett. 2006, 47, 2161-2164. doi:10.1016/j.tetlet.2006.01.119

23. Neely, W. J. Aust. J. Chem. 1960, 13, 341-346. doi:10.1071/CH9600341

24. Bollini, M.; Casal, J. J.; Alvarez, D. E.; Boiani, L.; González, M.; Cerecetto, H.; Bruno, A. M. Bioorg. Med. Chem. 2009, 17, 1437-1444. doi:10.1016/j.bmc.2009.01.011

25. Dyer, E.; Johnson, T. B. J. Am. Chem. Soc. 1932, 54, 777-787. doi:10.1021/ja01341a048

26. Dyson, G. M.; Harrington, T. J. Chem. Soc. 1942, 374-375. doi:10.1039/jr9420000374

27. Jochims, J. C.; Seeliger, A. Tetrahedron 1965, 21, 2611-2616. doi:10.1016/S0040-4020(01)93917-1

28. Gottfried, R. Angew. Chem., Int. Ed. Engl. 1966, 5, 963-964. doi:10.1002/anie.196609632

29. Larsen, C.; Steliou, K.; Harpp, D. N. J. Org. Chem. 1978, 43, 337-339. doi:10.1021/jo00396a035

30. Larsen, C.; Harpp, D. N. J. Org. Chem. 1981, 46, 2465-2466. doi:10.1021/jo00325a007

31. Kim, S.; Yi, K. Y. J. Org. Chem. 1986, 51, 2613-2615. doi:10.1021/jo00363a046

32. Kim, S.; Yi, K. Y. Tetrahedron Lett. 1985, 26, 1661-1664. doi:10.1016/S0040-4039(00)98578-2

33. Grayson, J. I. Org. Process Res. Dev. 1997, 1, 240-246. doi:10.1021/op970002c

34. Hodgkins, J. E.; Ettlinger, M. G. J. Org. Chem. 1956, 21, 404-405. doi:10.1021/jo01110a006

35. Hodgkins, J. E.; Reeves, W. P. J. Org. Chem. 1964, 29, 3098-3099. doi:10.1021/jo01033a524

36. Shibanuma, T.; Shiono, M.; Mukaiyama, T. Chem. Lett. 1977, 6, 573-574. doi:10.1246/cl.1977.573

37. Kondo, K.; Komamura, C.; Murakami, M.; Takemoto, K. Synth. Commun. 1985, 15, 171-177. doi:10.1080/00397918508063784

38. Yamamoto, T.; Terada, A.; Muramatsu, T.; Ikeda, K. Org. Prep. Proced. Int. 1994, 26, 555-557. doi:10.1080/00304949409458055

39. Boas, U.; Jakobsen, M. H. J. Chem. Soc., Chem. Commun. 1995, 1995-1996. doi:10.1039/C39950001995

40. Boas, U.; Pedersen, B.; Christensen, J. B. Synth. Commun. 1998, 28, 1223-1231. doi:10.1080/00397919808005964

41. Boas, U.; Gertz, H.; Christensen, J. B.; Heegaard, P. M. H. Tetrahedron Lett. 2004, 45, 269-272. doi:10.1016/j.tetlet.2003.10.182

42. Li, G.; Tajima, H.; Ohtani, T. J. Org. Chem. 1997, 62, 4539-4540. doi:10.1021/jo970100w

43. Isobe, T. J. Org. Chem. 1999, 64, 6984-6988. doi:10.1021/jo990210y

44. Bian, G.; Shan, W.; Su, W. J. Chem. Res. 2005, 585-586. doi:10.3184/030823405774308862

45. Chaskar, A. C.; Yewale, S.; Bhagat, R.; Langi, B. P. Synth. Commun. 2008, 38, 1972-1975. doi:10.1080/00397910801997744
46. Wong, R.; Dolman, S. J. J. Org. Chem. 2007, 72, 3969-3971. doi:10.1021/jo070246n

47. Bian, G.; Qiu, H.; Jiang, J.; Wu, J.; Lai, G. Phosphorus, Sulfur Silicon Relat. Elem. 2007, 182, 503-508. doi:10.1080/10426500600977379

48. Ghosh, H.; Yella, R.; Nath, J.; Patel, B. K. Eur. J. Org. Chem. 2008, 6189-6196. doi:10.1002/ejoc.200800901

49. Munch, H.; Hansen, J. S.; Pittelkow, M.; Christensen, J. B.; Boas, U. Tetrahedron Lett. 2008, 49, 3117-3119. doi:10.1016/j.tetlet.2008.03.045

50. Chaskar, A. C.; Bandgar, B. P.; Modhave, R. K.; Patil, A. B.; Yewale, S. Synth. Commun. 2009, 39, 992-1001. doi:10.1080/00397910802448481

51. Nath, J.; Ghosh, H.; Yella, R.; Patel, B. K. Eur. J. Org. Chem. 2009, 1849-1851. doi:10.1002/ejoc.200801270

52. Jamir, L.; Ali, A. R.; Ghosh, H.; Chipem, F. A. S.; Patel, B. K. Org. Biomol. Chem. 2010, 8, 1674-1678. doi:10.1039/b923336a

53. Yella, R.; Ghosh, H.; Murru, S.; Sahoo, S. K.; Patel, B. K. Synth. Commun. 2010, 40, 2083-2096. doi:10.1080/00397910903219476

54. Dains, F. B.; Brewster, R. G.; Olander, C. P. Organic Syntheses; John Wiley \& Sons: New York, NY, 1941; Vol. 1, p 447.

55. Moore, M. L.; Crossley, F. S. Organic Syntheses; John Wiley \& Sons: New York, NY, 1955; Vol. 3, p 599.

56. Li, Z.; Qian, X.; Liu, Z.; Li, Z.; Song, G. Org. Prep. Proced. Int. 2000, 32, 571-573. doi:10.1080/00304940009355953

57. van der Kerk, G. J. M.; Pluygers, C. W.; de Vries, G. Organic Syntheses; John Wiley \& Sons: New York, NY, 1973; Vol. 5, p 223.

58. Heusenstamm, G. G.; Schreyer, G.; Vanheertum, R. U.S. Patent 4,089,887, May 16, 1978.

59. Mesheram, H. M.; Dale, S.; Yadav, J. S. Tetrahedron Lett. 1997, 38 , 8743-8744. doi:10.1016/S0040-4039(97)10158-7

60. Furumoto, S. Nippon Kagaku Zasshi 1971, 92, 1005-1007. doi:10.1246/nikkashi1948.92.1005

61. Henke, K. R.; Hutchison, A. R.; Krepps, M. K.; Parkin, S.; Atwood, D. A. Inorg. Chem. 2001, 40, 4443-4447. doi:10.1021/ic0103188

62. Xiao, W.-J.; Alper, H. J. Org. Chem. 1999, 64, 9646-9652. doi:10.1021/j09913098

63. Sayigh, A. A. R.; Ulrich, H.; Potts, J. S. J. Org. Chem. 1965, 30 , 2465-2466. doi:10.1021/jo01018a511

64. Lieber, E.; Slutkin, R. J. Org. Chem. 1962, 27, 2214-2217. doi:10.1021/jo01053a509 


\section{License and Terms}

This is an Open Access article under the terms of the Creative Commons Attribution License

(http://creativecommons.org/licenses/by/2.0), which permits unrestricted use, distribution, and reproduction in any medium, provided the original work is properly cited.

The license is subject to the Beilstein Journal of Organic Chemistry terms and conditions:

(http://www.beilstein-journals.org/bjoc)

The definitive version of this article is the electronic one which can be found at:

doi:10.3762/bjoc.8.6 